\title{
Laser-ablation ICP-MS analysis of
} silicate and sulfide melt inclusions in an andesitic complex I Analytical approach and data evaluation

\author{
Journal Article \\ Author(s): \\ Halter, Werner E.; Pettke, Thomas; Heinrich, Christoph A. (D) \\ Publication date: \\ 2004-06 \\ Permanent link: \\ https://doi.org/10.3929/ethz-b-000050505 \\ Rights / license: \\ In Copyright - Non-Commercial Use Permitted \\ Originally published in: \\ Contributions to Mineralogy and Petrology 147(4), https://doi.org/10.1007/s00410-004-0562-6
}


Werner E. Halter · Thomas Pettke

Christoph A. Heinrich

\section{Laser-ablation ICP-MS analysis of silicate and sulfide melt inclusions in an andesitic complex I: analytical approach and data evaluation}

Received: 17 December 2002/ Accepted: 16 January 2004 / Published online: 6 April 2004

(C) Springer-Verlag 2004

\begin{abstract}
Quantitative microanalysis of entire silicate and sulfide melt inclusions by Excimer Laser-ablation inductively-coupled-plasma mass-spectrometry (LA-ICPMS) has been applied to extrusive and shallow intrusive rocks from the andesitic Farallón Negro Volcanic Complex (northwestern Argentina). Silicate melts are trapped in pyroxene, amphibole, plagioclase and quartz, and sulfide melts are trapped in amphibole. Details of the analytical approach and the quantification procedure are given and the results are evaluated to test the accuracy of the technique and the validity of the interpretation of analytical signals. Similar compositions of silicate melt inclusions trapped in truly co-precipitating minerals show that the quantification approach of melt inclusion compositions from LA-ICPMS signals through an internal standard is valid. This correspondence also shows that melt inclusions investigated in this study are not significantly influenced by the boundary layer around a growing crystal or by post-entrapment modifications. Post-entrapment diffusive re-equilibration only affected the $\mathrm{Fe}$ and $\mathrm{Mg}$ content of melt inclusions in mafic phases. Thus, melt inclusions are representative samples of the melt from which the host mineral crystallized, with regard to most major and trace elements. Sulfide melt inclusions (present as pyrrhotite with exsolution of $\mathrm{Au}$ and $\mathrm{Cu}$ in phases separated during cooling) were analyzed for their bulk $\mathrm{Fe}, \mathrm{Cu}$ and $\mathrm{Au}$ content, and the abundance of these elements was quantified using a silicate glass as external standard. The validity of this calibration was tested by comparing electron microprobe analyses of $\mathrm{Fe}, \mathrm{Cu}, \mathrm{Ni}$ and $\mathrm{Co}$ in homogeneous sulfide minerals with LA-ICPMS results.
\end{abstract}

Editorial responsibility: T.L. Grove

W. E. Halter $(\bowtie) \cdot$ T. Pettke $\cdot$ C. A. Heinrich Isotope Geochemistry and Mineral Resources, Department of Earth Sciences, ETH Zurich,

8092 Zurich, Switzerland

E-mail: halter@erdw.ethz.ch

Tel.: +41-1-6326802

Fax: + 41-1-6321827
Identical results within calculated uncertainty (one standard deviation of five to nine analyses, mostly between 1 and $5 \mathrm{wt} \%$ RSD) demonstrate that for these elements, measured element ratios are independent of the matrix using our analytical setup.

\section{Introduction}

With new developments in analytical techniques, melt inclusions have become an increasingly powerful source of information about processes in magmatic systems (Anderson and Brown 1993; Hauri et al. 2002; Sobolev and Chaussidon 1996; Sobolev and Shimizu 1993; Wallace et al. 1995). Provided that such inclusions are representative samples of the melt from which a phase has crystallized in the magma, they yield unique constraints on the changes in melt compositions during magma evolution (e.g., Lowenstern 1994). Electron and ion microprobe analysis are applicable to homogeneous inclusions quenched to a glass, naturally or through homogenization runs in the laboratory, and then exposed in a polished section. In basalts, melt inclusion studies have applied these techniques with success (Danyushevsky et al. 2002a; Kamenetsky and Clocchiatti 1996; Metrich et al. 1993; Sobolev 1996; Webster et al. 1999). In water-rich, intermediate to felsic volcanic rocks, and particularly in subvolcanic intrusions that commonly give rise to hydrothermal mineralization, melt inclusions are rarely glassy (Dietrich et al. 2000) and commonly difficult to re-homogenize by heating (e.g. Campos et al. 2002; Dietrich et al. 2000). Sulfide melt inclusions are extremely difficult to quench, even with a rapid heating/quenching stage (Sobolev et al. 1980) and representative analysis of their composition with common microprobe techniques is therefore very challenging (Alard et al. 2000; Larocque et al. 2000).

Laser-ablation inductively-coupled-plasma massspectrometry (LA-ICPMS) has been successfully applied to the analysis of major to trace elements in exposed 
homogeneous melt inclusions (Taylor et al. 1997; Kamenetsky et al. 1998). Building on these studies, we exploited the additional, decisive advantage of this technique that entire, heterogeneous inclusions can be ablated and analyzed quantitatively in any host phase. Thus, prior homogenization of inclusions by heating is no longer a prerequisite for their representative analysis. This includes very water-rich inclusions that lose volatiles upon heating, or inclusions of sulfide melts, which are notoriously difficult to quench. It permits the investigation of specific magmatic processes, including the genesis of andesites, the formation of water-saturated intrusions, the exsolution of volatile phases, the formation of magmatic-hydrothermal fluids and associated ore deposits and the behavior of ore metals during magma evolution in sulfide saturated igneous systems. In addition, the analysis of inclusions in coexisting phases allows a critical evaluation of the starting hypothesis that melt inclusions are indeed representative of the melt composition at the time of their entrapment.

In this contribution, we present details of the analytical procedure used to quantify melt inclusion compositions in an andesitic system that includes co-magmatic volcanic and subvolcanic intrusive rocks. We evaluate precision, accuracy and the influence of post-entrapment modifications on the derived melt composition. Samples used for this study are part of an integrated study of the Farallón Negro Volcanic Complex (FNVC) in northwestern Argentina, which hosts the large Bajo de la Alumbrera porphyry $\mathrm{Cu}-\mathrm{Au}$ deposit. The geological background is documented in Halter et al. (2004a) and the geochemical interpretation of the melt inclusion data and their significance for magmatic and ore-forming processes are presented in the following companion paper by Halter et al. (2004b) and Halter et al. (2002a).

\section{Melt inclusion petrography}

The Farallón Negro Volcanic complex in northwestern Argentina formed between 9.6 and $6.3 \mathrm{Ma}$ and consists of a large stratovolcano with basaltic to dacitic flows, intruded by numerous shallow porphyry stocks of basaltic-andesitic to rhyodacitic composition (Llambías 1970). Each stock is formed of several intrusions, depicting a range in compositions. Samples were selected to represent various stages in the volcanic sequence and most of the intrusive stocks. Details are given in Halter et al. (2004a) and Halter et al. (2004b).

Silicate melt inclusions were analyzed in phenocrysts of pyroxene, amphibole, plagioclase and quartz in fresh and slightly altered rocks. The inclusions are either crystallized or glassy and both types can co-exist in the growth zones of a given crystal. Their apparent size ranges from a few to approximately $50 \mu \mathrm{m}$, the largest ones being trapped in quartz and pyroxene (Fig. 1). Many inclusions show evidence for crystallization onto inclusion walls. In pyroxene (Fig. 1A) this is apparent from large bubbles and from daughter phases that are partly surrounded by the host mineral. Similar or even more pronounced textures of this type are found in amphibole (Fig. 1B). Melt inclusions in pyroxene are abundant in volcanic rocks, but nearly absent in intrusions. Within mafic phases, melt inclusions have a wide range in size, and are randomly distributed (Fig. 1A), suggesting trapping during continuous growth of the host crystals. In plagioclase, inclusions occur mostly as populations along growth zones (Fig. 1C). Inclusions in quartz can have either of these two occurrences (Fig. 1D).

Sulfides were trapped as primary inclusions in some amphibole crystals only (Fig. 1E). These sulfides are generally less than $10 \mu \mathrm{m}$ across and occur in clusters of a few to some 30 inclusions. The larger inclusions have very irregular shapes (Halter et al. 2004b) suggesting entrapment as a liquid phase.

\section{Data acquisition}

Individual melt inclusions were analyzed using an Excimer laser-ablation inductively-coupled-plasma massspectrometry (LA-ICPMS) system. Melt compositions and their uncertainties were quantified following the procedure described in Halter et al. (2002b). Since inclusions are not homogenized to a glass, critical data evaluation has to be applied to identify inclusions that are not representative of a melt because of heterogeneous entrapment or because they behaved as open systems after entrapment. This is done by analyzing several inclusions in a given assemblage of simultaneously trapped inclusions (e.g., on a same growth zone), which is easily possible given that only a few minutes are necessary for each LA-ICPMS measurement. Analyses are considered representative of the melt only if they yield consistent results within an inclusions assemblage. Individual inclusions or outliers were not reported in tables and figures.

\section{Analytical procedure}

Entire unexposed melt inclusions 5 to $30 \mu \mathrm{m}$ beneath the sample surface were considered for analysis, to avoid non-representative sampling of heterogeneous inclusions due to loss of daughter crystals. Inclusions were ablated using an optically homogenized UV beam from a $193 \mathrm{~nm}$ ArF Eximer laser (Gunther et al. 1997) and details of run conditions are reported in Table 1 . The size of the laser spot can be adjusted between 8 and $80 \mu \mathrm{m}$ using pinhole apertures. For each inclusion, the pit size was selected to be slightly larger than the inclusion diameter (Fig. 1F). The ablated material was transported by He carrier gas to an Elan 6100 quadrupole mass-spectrometer, which sequentially records signals for all the elements of interest. Ablation was monitored through an optical microscope and the recorded signal was displayed in real time on a computer 

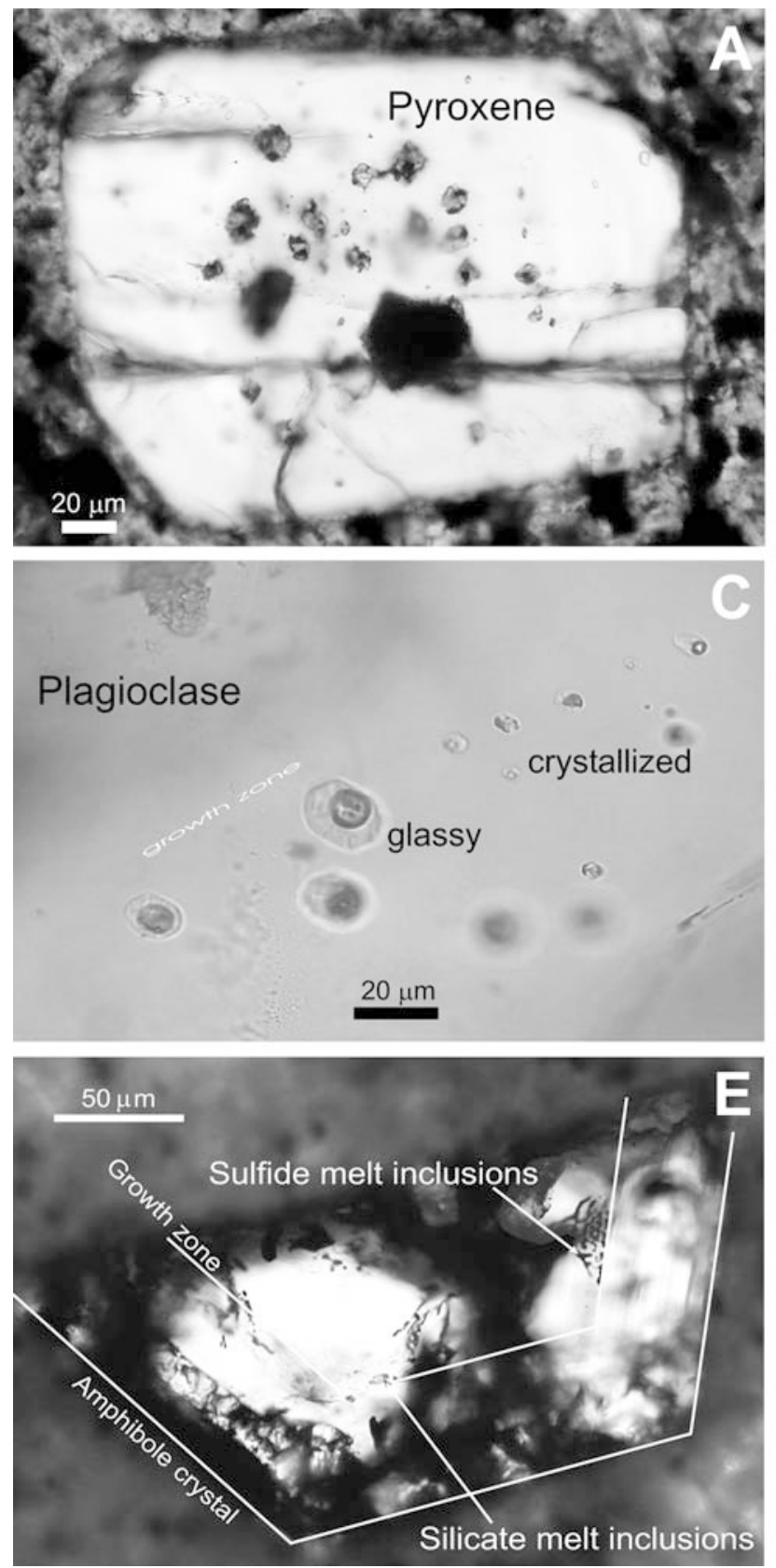

Fig. 1 Examples of melt inclusions analyzed in various host minerals. Inclusions in pyroxene (A) and amphibole (B) are generally glassy and contain daughter crystals. In pyroxene (A), melt inclusions commonly have an opaque daughter crystal and a large bubble (10 to $20 \mathrm{vol} \%)$. The large shrinkage bubble, particularly in amphibole, suggests extensive crystallization of host mineral onto the inclusion walls. Inclusions in plagioclase $(\mathbf{C})$ are characterized by negative crystal shapes and are often crystallized, except in late intrusions. In the latter case, melt inclusions contain bubbles of approximately $20 \mathrm{vol} \%$. Quartz phenocrysts host both glassy and finely crystallized melt inclusions (D) with bubbles of 20 to $30 \mathrm{vol} \%$. These inclusions have a negative crystal shape and often depict small cracks at opposite corners. Sulfide melt inclusions (E) are very irregular in shape and trapped only in amphibole. Inclusions were analyzed by using laser beam sizes slightly larger than the inclusion and an example of resulting pits are shown in $(\mathbf{F})$. Only inclusions entirely enclosed in the host mineral were analyzed, inclusions that were not analyzed are partly exposed to the sample surface
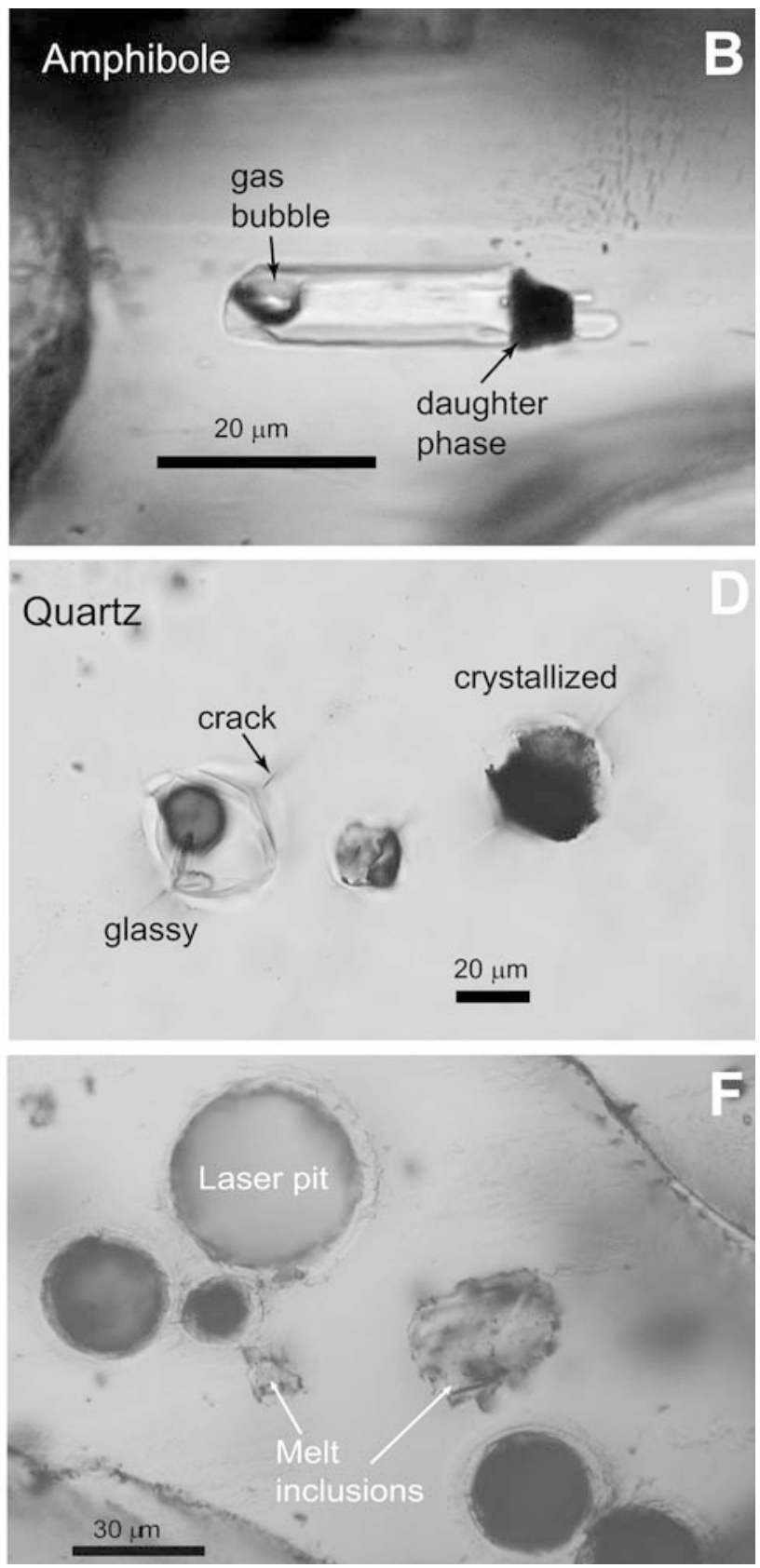

monitor to guarantee maximum control of the ablation procedure. Each transient signal is composed of 20 to $30 \mathrm{~s}$ of instrument background measurement, followed by the analytical signal from the ablation of the host mineral and the inclusion (Fig. 2). The analytical signal is composed of a steady response from the ablation of the host mineral before and after the inclusion, and an intermediate transient signal from the combined ablation of host and inclusion in varying proportions. The analytical setup is described in detail by Gunther et al. (1997) and Heinrich et al. (2002) and the validity of its application to melt inclusions in recent volcanic rocks has been tested by Pettke et al. (2002).

Sulfide melts were analyzed using the same approach as described for silicate melt inclusions (Halter et al. 
Table 1 LA-ICPMS machine and data acquisition parameters

Excimer $193 \mathrm{~nm}$ ArF laser Compex 110I

Output energy

Pulse duration/repetition rate

Pit size

Cell He gas flow

ELAN 6100 DRC quadrupole ICP-MS

Nebulizer gas flow

Auxiliary gas flow

Cool gas flow

rf power

Detector mode

Detector housing vacuum

Data acquisition parameters

Readings per replicate

Dwell time per isotope

Isotopes
Adjusted to between 27 and $200 \mathrm{~mJ}$ at $193 \mathrm{~nm}$

$15 \mathrm{~ns} / 10 \mathrm{~Hz}$

Between 8 and $80 \mu \mathrm{m}$

Optimized between 0.9 and $1.21 \mathrm{~min}^{-1}$

Optimized between 0.95 and $1.201 \mathrm{~min}^{-1} \mathrm{Ar}$ Optimized between 0.75 and $1.001 \mathrm{~min}^{-1} \mathrm{Ar}$

Optimized between 14.0 and $16.01 \mathrm{~min}^{-1} \mathrm{Ar}$

Optimized between 1,450 and $1,550 \mathrm{kV}$

Dual, up to 9 orders of magnitude linear dynamic range

Between 1.5 and $2.8 \times 10^{-5}$ Torr during analysis

Between 200 and 1,000 as a function of number of isotopes

Adjusted between $10 \mathrm{~ms}$ (standard) and $30 \mathrm{~ms}$ (to lower LOD)

${ }^{23} \mathrm{Na},{ }^{25} \mathrm{Mg},{ }^{27} \mathrm{Al},{ }^{29} \mathrm{Si}{ }^{39} \mathrm{~K},{ }^{42} \mathrm{Ca},{ }^{49} \mathrm{Ti},{ }^{55} \mathrm{Mn},{ }^{57} \mathrm{Fe},{ }^{65} \mathrm{Cu}{ }^{66} \mathrm{Zn},{ }^{85} \mathrm{Rb},{ }^{88} \mathrm{Sr},{ }^{89} \mathrm{Y},{ }^{90} \mathrm{Zr}$ ${ }^{93} \mathrm{Nb},{ }^{95} \mathrm{Mo},{ }^{133} \mathrm{Cs},{ }^{137} \mathrm{Ba},{ }^{139} \mathrm{La},{ }^{140} \mathrm{Ce},{ }^{146} \mathrm{Nd},{ }^{173} \mathrm{Yb},{ }^{175} \mathrm{Lu},{ }^{181} \mathrm{Ta},{ }^{208} \mathrm{~Pb},{ }^{232} \mathrm{Th},{ }^{238} \mathrm{U}$

Fig. 2 Typical ablation signals for selected elements (from a 27-element menu) in silicate melt inclusions in pyroxene (A), amphibole (B), plagioclase (C) and quartz (D). With time, the signal records (I) the plasma background, (II) the signal from the host only, (III) a mixed signal from the host and the inclusions in an evolving proportion and (IV) the signal from the host below the inclusion. After ablation of the entire inclusion, the analysis was stopped
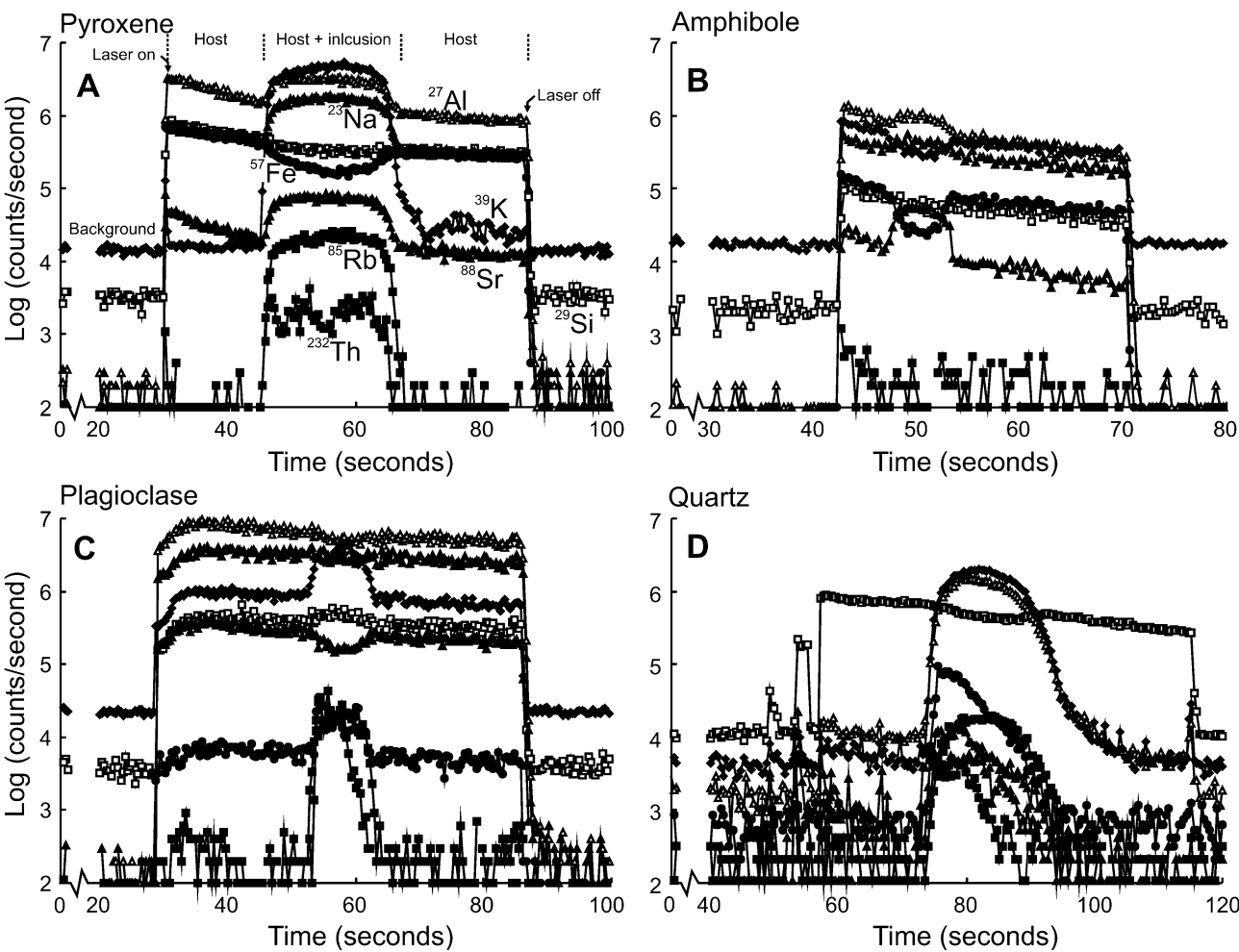

2002b). A typical signal obtained from the analysis of a sulfide melt inclusion in amphibole is shown in Fig. 3. As for silicate inclusions, the signal consists of a background measurement, monitored prior to ablation, a signal from the host before and after the ablation of the inclusion and an evolving signal of host plus inclusion mixture. Note the conspicuous internal heterogeneity of the sulfide melt inclusion.

\section{Quantification of melt inclusion compositions}

Quantification of the chemical composition of silicate melt inclusions is obtained through a three-step procedure. First, analytical signals of the host and the host plus inclusion mixture are converted into element ratios using element sensitivity factors determined through bracketing external standards (SRM-610 from NIST, hereafter NIST 610). Second, element concentrations in the host and the mixed segment are calculated by normalizing to a total concentration of major elements of $100 \mathrm{wt} \%$ (or less if a certain water concentration is expected). Finally, the relative contributions of the host and the inclusions to element concentrations in the mixed host + inclusion signal need to be assessed, to determine element concentrations in the originally trapped melt. This is done for each inclusion using an internal standard (Halter et al. 2002b). An internal standard is a known element concentration in the melt, by which the mass ratio between the host and the 
Fig. 3 Typical signal obtained from the ablation of a sulfide melt inclusion in amphibole. Important to note is that the composition of the inclusion is highly heterogeneous, hence element ratios vary during ablation. Thus, only complete ablation of the inclusion provides a representative analysis of the trapped melt

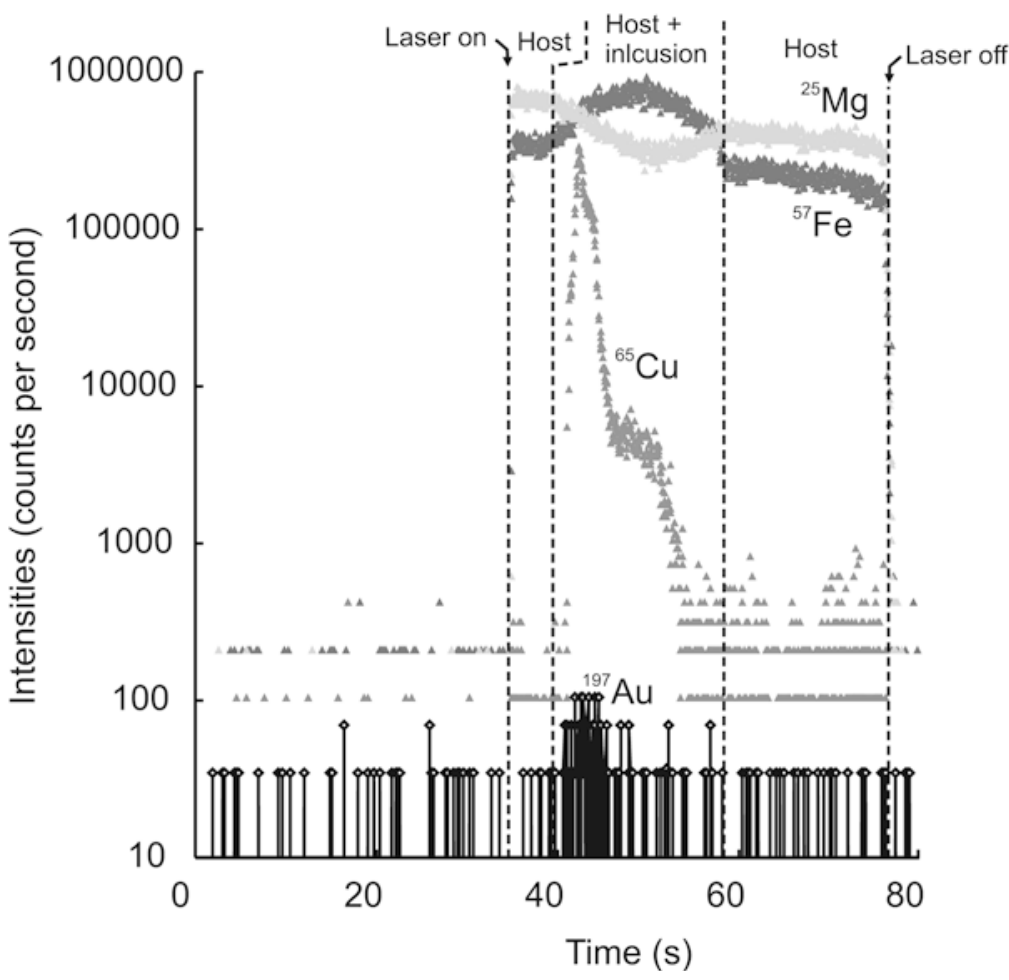

inclusion can be uniquely determined. Once the inclusion/host ratio is known, the concentration of all the elements in the melt can be quantified through a simple mathematical procedure, graphically presented in Fig. 4.

An internal standard can be obtained through several methods, discussed by Halter et al. (2002b). In the FNVC, the best choice for an internal standard comes from the tight correlation between $\mathrm{FeO}$ and $\mathrm{Al}_{2} \mathrm{O}_{3}$ content of bulk rocks (Fig. 4). Varying the relative mass of host and inclusion in a given analysis modifies the calculated element ratio in the melt, thus the assumption that melt inclusions have similar $\mathrm{FeO} / \mathrm{Al}_{2} \mathrm{O}_{3}$ ratios as bulk rocks uniquely defines the concentrations of both $\mathrm{FeO}$ and $\mathrm{Al}_{2} \mathrm{O}_{3}$ in the inclusion and, thus, the mass ratio (Halter et al. 2002b).

During cooling after melt inclusion entrapment, a considerable quantity of host mineral crystallizes from the melt onto the inclusion wall. Element concentrations obtained during ablation of the host + inclusion mixture include this newly crystallized wall and an unknown amount of additional host mineral. The use of an internal standard has the advantage that no prior knowledge of the amount of crystallization onto the inclusion wall is required since it is ablated with the residual inclusion melt during the analysis and the bulk of the ablated material is used for quantification. Thus, re-melting of the inclusion wall is not necessary for this analytical approach.

Sulfide melt inclusions were quantified using the same approach and the same external standard as for silicate melt inclusions, i.e., a silicate glass NIST 610. Sulfur was not quantified and element concentrations were obtained by assuming that the inclusion was stoichiometric
$(\mathrm{Fe}, \mathrm{Cu}) \mathrm{S}$ with sufficiently small $\mathrm{Cu}$ concentration (max. $3 \mathrm{wt} \%$ ) that the valence and stoichiometric state of $\mathrm{Cu}$ is irrelevant within the analytical uncertainty $(5-10 \mathrm{wt} \%)$. The mass ratio between the inclusion and the host was calculated by assuming that the inclusion contained no silica, i.e., elements contributions from the host mineral (essentially Fe from amphibole in this case) were subtracted in proportion of the $\mathrm{SiO}_{2}$ content of the host mineral. To increase the number of determinations and the counting time on $\mathrm{Au}$, the number of elements analyzed was reduced to four ( $\mathrm{Si}, \mathrm{Fe}, \mathrm{Cu}, \mathrm{Au}$ ). This significantly decreased the uncertainty and the limit of detection for $\mathrm{Au}$ and granted a more representative sampling (Pettke et al. 2000) of the commonly short $\mathrm{Au}$ signal generated from tiny nuggets formed upon solidification of the sulfide melt.

Individual analyses of silicate and sulfide melt inclusions and the host mineral for each inclusion are available as an electronic data repository of the companion paper (Halter et al. 2004b).

\section{Uncertainties and limits of detections}

Analytical uncertainties in element concentrations are the combined result of plasma flickering (evident from the rapid, short term fluctuation in the signal; Fig. 2), counting statistics, and the restricted number of determinations of a given element during analysis. These uncertainties can be quantified and were propagated through the calculations of element concentrations for each inclusion (Halter et al. 2002b). A large contribution of the host to the total measured element concentrations 


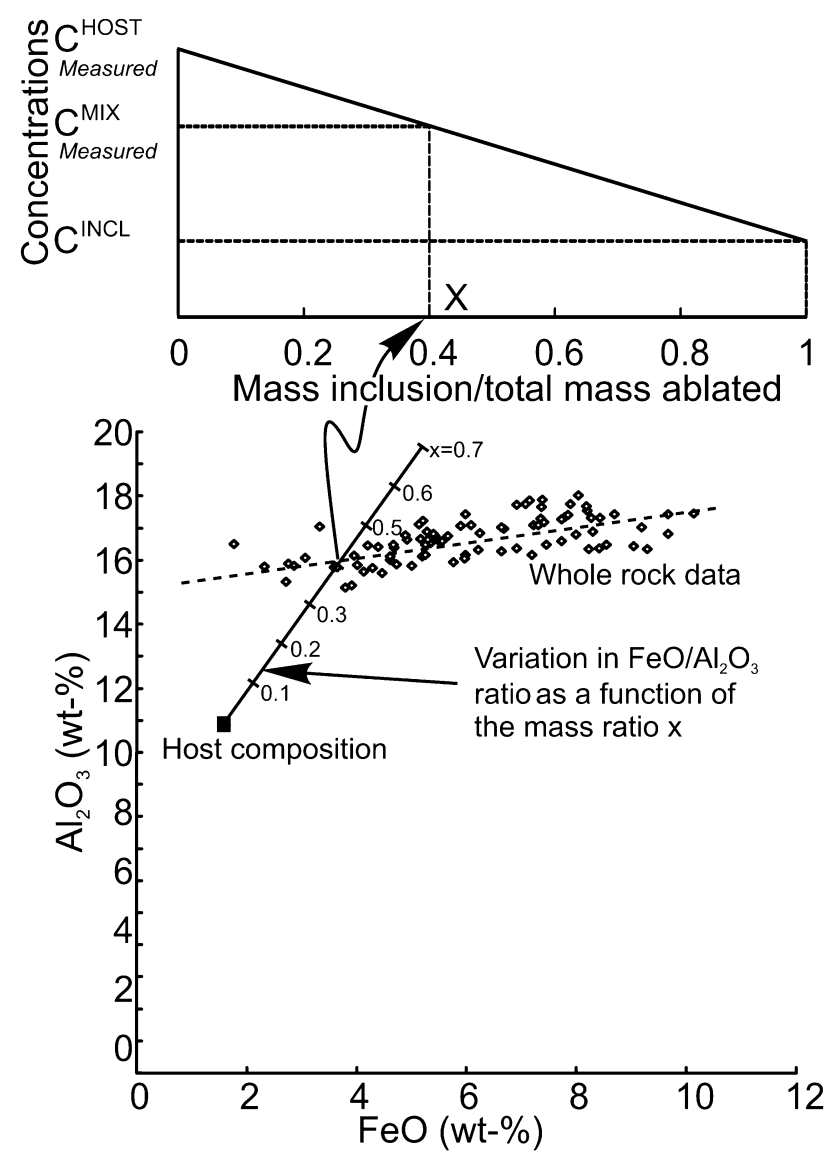

Fig. 4 Successive steps in the quantification of element concentrations in melt inclusions. The correlation between $\mathrm{FeO}$ and $\mathrm{Al}_{2} \mathrm{O}_{3}$ in whole rocks constrains the concentration of $\mathrm{Al}_{2} \mathrm{O}_{3}$ in the inclusions, which is used as an internal standard. The mass ratio between the host mineral and the melt inclusions is used to quantify concentrations of all other elements in the inclusions. Modified from Halter et al. (2002b)

in the mixed signal increases the uncertainty on the inclusion composition. Thus, analyses were only retained if the melt contribution to the mixed signal was more than $20 \mathrm{wt} \%$. Limits of detection for major to trace element concentrations in melt inclusions vary between a few thousand and a few ppm, depending on the compositions of the host mineral and the mass ratio between the inclusion and the host mineral in the mixed ablation interval (Fig. 2). Analytical uncertainties on element concentrations of a single melt inclusion are on the order of 2 to $30 \%$ depending on the element and increase rapidly with increasing host/inclusion ratio.

Additional uncertainty results from the signal de-convolution and depends on the accuracy with which the internal standard is determined. Quantification using the $\mathrm{FeO} / \mathrm{Al}_{2} \mathrm{O}_{3}$ leads to small uncertainties because the $\mathrm{Al}_{2} \mathrm{O}_{3}$ content varies only between 18 and $14 \mathrm{wt} \%$ over the entire differentiation trend, so that the adjustment to the $\mathrm{FeO} / \mathrm{Al}_{2} \mathrm{O}_{3}$ ratio is a second-order correction only (Fig. 4). Results are therefore also not sensitive to uncertainties in the $\mathrm{Fe}^{2+} / \mathrm{Fe}^{3+}$ ratio of melts or phenocrysts, or to some post-entrapment modification of
$\mathrm{Fe} / \mathrm{Mg}$ (see below). Other element correlations such as $\mathrm{TiO}_{2} / \mathrm{Al}_{2} \mathrm{O}_{3}$ or $\mathrm{CaO} / \mathrm{SiO}_{2}$ were also used to test the accuracy of the $\mathrm{FeO} / \mathrm{Al}_{2} \mathrm{O}_{3}$ ratio as an internal standard but these ratios are not universally applicable because of the high compatibility of $\mathrm{Ti}$ and $\mathrm{Ca}$ in some minerals and their low abundance in highly fractionated melts. Using the correlation between $\mathrm{FeO}$ and $\mathrm{Al}_{2} \mathrm{O}_{3}$ as an internal standard, variations in the concentration of most elements closely follow those of whole rocks (Halter et al. 2004b), justifying the use of this internal standard. To illustrate that results are rather insensitive to these assumptions, we report in Table 2 the composition of a melt inclusion in pyroxene, quantified using the $\mathrm{Al}_{2} \mathrm{O}_{3}$ content derived from the bulk rock chemical trend and deviations of $1 \mathrm{wt} \%$ from this concentration, which covers half of the entire range in the $\mathrm{Al}_{2} \mathrm{O}_{3}$ concentrations of the parent magmas. Table 2 shows that most calculated element concentrations are not significantly affected by this uncertainty on a carefully selected internal standard. As this uncertainty cannot be quantified for each analysis, it was not included in the calculation.

Differences between the melt and the bulk rock compositions also result from equilibrium crystallization of phenocrysts. In the FNVC, the most abundant phenocrysts are amphibole and plagioclase, and the precipitation of these two phases has opposing effects on the $\mathrm{Al}_{2} \mathrm{O}_{3}$ content of the melt. Some rocks contain only amphibole and crystallization of $20 \%$ amphibole phenocrysts will raise the $\mathrm{Al}_{2} \mathrm{O}_{3}$ content of the residual melt by $1.7 \mathrm{wt} \%$. The average amount of amphibole phenocrysts in these rocks is well below $20 \%$ and this effect is therefore expected to be of similarly subordinate importance to the result.

\section{Influence of the host mineral and significance of the data}

A first requirement underlying any petrogenetic use of melt inclusions is the assumption that inclusions are truly representative of the melt in which the host mineral grew. In particular, boundary layer effects (i.e., a melt layer of different composition from the bulk melt surrounding growing crystals) have been suggested as a potential mechanism that could affect the representativity of melt inclusions. To evaluate the significance of this effect, we analyzed inclusions in two distinct phases where petrographic criteria indicate that they crystallized simultaneously. Note that such pairs are rarely found in the system under investigation and evidence from melt inclusions suggest that phases generally do not co-exist (see Halter et al. 2004b). The selected inclusions are from a plagioclase-pyroxene pair and an amphibole-plagioclase pair in a volcanic and an intrusive rock, respectively. With the exception of $\mathrm{Fe}$ and $\mathrm{Mg}$, which have abundances that do not overlap within their uncertainly, and $\mathrm{Cu}$ in the plagioclase-pyroxene pair, the relative abundance of element concentrations in the two pairs is mostly identical within their uncertainty (Fig. 5). 
Table 2 Effect of an uncertainty of $1 \mathrm{wt} \% \mathrm{Al}_{2} \mathrm{O}_{3}$ on the calculated composition of a melt inclusion trapped in pyroxene

\begin{tabular}{|c|c|c|c|c|c|}
\hline \multicolumn{6}{|c|}{ Internal standards: } \\
\hline \multicolumn{2}{|c|}{$\begin{array}{l}\mathrm{Al}_{2} \mathrm{O}_{3} \text { from bulk } \\
\text { fractionation trend }\end{array}$} & \multicolumn{2}{|c|}{$\begin{array}{l}\text { Fractionation } \\
\text { trend }-1 \mathrm{wt}^{\mathrm{o}} \% \\
\mathrm{Al}_{2} \mathrm{O}_{3}\end{array}$} & \multicolumn{2}{|c|}{$\begin{array}{l}\text { Fractionation } \\
\text { trend }+1 \mathrm{wt} \% \\
\mathrm{Al}_{2} \mathrm{O}_{3}\end{array}$} \\
\hline & & & Deviation & & Deviation \\
\hline $\mathrm{SiO}_{2}$ & 58.95 & 58.16 & $1 \%$ & 59.74 & $-1 \%$ \\
\hline $\mathrm{TiO}_{2}$ & 0.32 & 0.34 & $-7 \%$ & 0.30 & $7 \%$ \\
\hline $\mathrm{Al}_{2} \mathrm{O}_{3}$ & 16.45 & 15.45 & $6 \%$ & 17.45 & $-6 \%$ \\
\hline $\mathrm{Fe}_{2} \mathrm{O}_{3}$ & 5.91 & 6.24 & $-6 \%$ & 5.57 & $6 \%$ \\
\hline $\mathrm{MnO}$ & 0.15 & 0.17 & $-12 \%$ & 0.13 & $12 \%$ \\
\hline $\mathrm{MgO}$ & 2.79 & 3.66 & $-31 \%$ & 1.92 & $31 \%$ \\
\hline $\mathrm{CaO}$ & 4.04 & 5.13 & $-27 \%$ & 2.96 & $27 \%$ \\
\hline $\mathrm{Na}_{2} \mathrm{O}$ & 3.19 & 2.97 & $7 \%$ & 3.41 & $-7 \%$ \\
\hline $\mathrm{K}_{2} \mathrm{O}$ & 4.20 & 3.88 & $8 \%$ & 4.52 & $-8 \%$ \\
\hline $\mathrm{H}_{2} \mathrm{O}$ & 4.00 & 4.00 & & 4.00 & \\
\hline Total & 100.00 & 100.00 & & 100.00 & \\
\hline $\mathrm{Cu}$ & 67 & 62 & $7 \%$ & 72 & $-7 \%$ \\
\hline $\mathrm{Zn}$ & 37 & 39 & $-6 \%$ & 35 & $6 \%$ \\
\hline $\mathrm{Rb}$ & 129 & 119 & $8 \%$ & 139 & $-8 \%$ \\
\hline $\mathrm{Sr}$ & 350 & 326 & $7 \%$ & 374 & $-7 \%$ \\
\hline $\mathrm{Y}$ & 22 & 23 & $-4 \%$ & 21 & $4 \%$ \\
\hline $\mathrm{Zr}$ & 172 & 162 & $6 \%$ & 182 & $-6 \%$ \\
\hline $\mathrm{Nb}$ & 16 & 14 & $8 \%$ & 17 & $-8 \%$ \\
\hline Mo & 2 & 2 & $7 \%$ & 2 & $-7 \%$ \\
\hline $\mathrm{Ba}$ & 464 & 429 & $8 \%$ & 500 & $-8 \%$ \\
\hline Cs & 6 & 6 & $8 \%$ & 7 & $-8 \%$ \\
\hline $\mathrm{La}$ & 26 & 24 & $7 \%$ & 28 & $-7 \%$ \\
\hline $\mathrm{Ce}$ & 50 & 47 & $5 \%$ & 52 & $-5 \%$ \\
\hline $\mathrm{Nd}$ & 22 & 22 & $2 \%$ & 22 & $-2 \%$ \\
\hline $\mathrm{Yb}$ & 2 & 2 & $-9 \%$ & 2 & $9 \%$ \\
\hline $\mathrm{Ta}$ & 1 & 1 & $7 \%$ & 1 & $-7 \%$ \\
\hline $\mathrm{Pb}$ & 12 & 11 & $8 \%$ & 12 & $-8 \%$ \\
\hline $\mathrm{Th}$ & 9 & 8 & $8 \%$ & 10 & $-8 \%$ \\
\hline $\mathrm{U}$ & 3 & 3 & $8 \%$ & 3 & $-8 \%$ \\
\hline Mass factor & 0.44 & 0.47 & & 0.41 & \\
\hline
\end{tabular}

Major elements are in $\mathrm{wt}^{\mathrm{O}} \%$, trace elements in $\mathrm{ppm}$

This result has several implications. First, it confirms that calculated compositions of the melt inclusions are not biased by the composition of the host mineral phases during signal de-convolution, even though some compatible major or trace elements have up to 5 times smaller concentrations in the melt than in the host. This is evidence that the analytical approach using heterogeneous inclusions and the selected internal standard are valid and yield correct inclusion compositions. The plots also illustrate that uncertainties can differ significantly depending on whether an element is compatible or incompatible in the host mineral, and that the calculated de-convolution uncertainties are a good measure of the overall uncertainty. For instance, the uncertainty on $\mathrm{Sr}$ is much higher in plagioclase than in pyroxene, because the high $\mathrm{Sr}$ content of the plagioclase dominates the mixed signal. Conversely, $\mathrm{Zn}$ concentrations are more accurately determined in plagioclase than in the pyroxene, because the $\mathrm{Zn}$ concentration in plagioclase is lower than in the pyroxene (Fig. 5a).

Consistent melt compositions in contrasting host minerals also imply that the boundary layer around the growing crystal has little or no effect on the composition
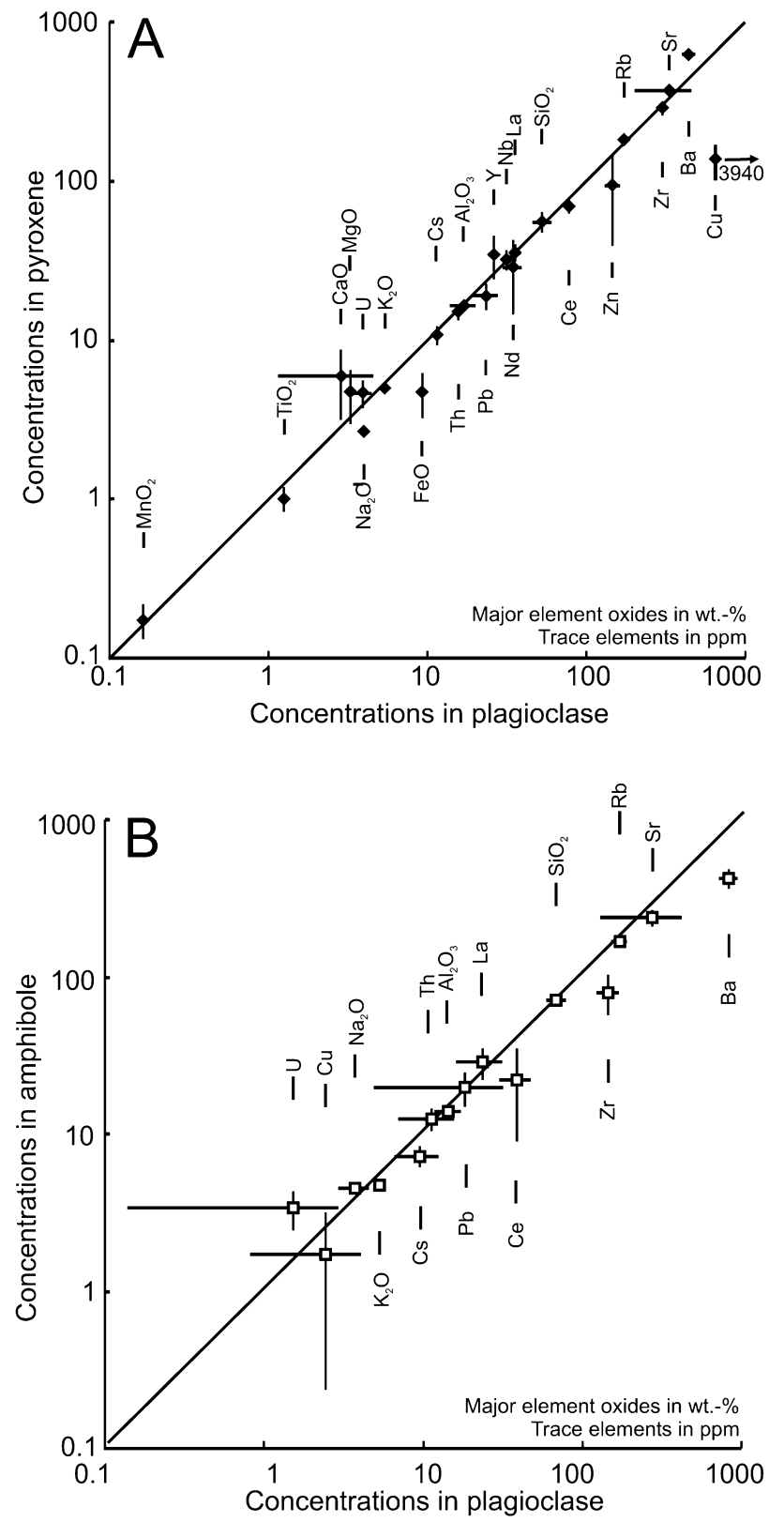

Fig. 5 Comparison between element concentrations in melt inclusions from a co-existing plagioclase-pyroxene pair in a volcanic rock (A) (sample NB5B), and a plagioclase-amphibole pair from an intrusive rock (B) (sample NB32B). Nearly all the elements have identical concentrations (within their uncertainty) in both pairs of inclusions, demonstrating the validity of the analytical procedure, notably the de-convolution of the mixed signal to calculate element concentrations in the inclusion and that element concentration in melt inclusions are not extensively modified by post-entrapment diffusion or boundary layer phenomena around growing crystals. Major elements are in $\mathrm{wt}^{\mathrm{m}} \%$ and trace elements in $\mathrm{ppm}$

of the melt inclusions. If boundary-layer effects were significant, host mineral specific deviations would be expected depending on whether an element is compatible or incompatible in one or the other host mineral. Thomas et al. (2002) have similarly concluded from electron microprobe studies of glassy melt inclusions in various 
co-genetic phases from the Toba Tuff that melt inclusions of $20 \mu \mathrm{m}$ or larger are representative samples of the bulk melt.

\section{Post-entrapment modifications}

A second requirement for interpretable melt inclusion data is that inclusions were preserved as a closed system after entrapment, i.e., that the composition of the inclusion and the host mineral that crystallized from the inclusion did not exchange with the surrounding mineral or melt. Calculations suggest that significant diffusion of elements under strong chemical gradients can significantly modify the concentration of some elements in melt inclusions (Gaetani and Watson 2000). From Fig. 5, post entrapment diffusion can be discarded as a process that significantly affects melt inclusion compositions because it would be unexpected coincidence if these modifications were identical in highly contrasting host minerals. Diffusion rates for various elements are significantly different in plagioclase, pyroxene and amphibole and diffusion would affect element concentrations to various extents in different minerals.

Iron and magnesium deviate significantly in their concentrations in the pyroxene - plagioclase pair (in Fig. 5B both elements are below the limit of detection in inclusions in amphibole and could not be compared). The concentration of $\mathrm{Fe}$ is lower (5 to $10 \%$ relative), and that of $\mathrm{Mg}$ is higher in inclusions trapped in pyroxene and amphibole, compared to inclusions in plagioclase or in the bulk rock at similar silica content (Fig. 6). Moreover, $\mathrm{Mg} \#$ [the $\mathrm{Mg}$-number $\mathrm{Mg} /(\mathrm{Mg}+\mathrm{Fe})$, in mol] in host minerals and inclusions are similar, i.e., their ratio is close to 1 . This is incompatible with frozen equilibrium conditions between the two phases which fixes the ratio between the $\mathrm{Mg \#}$ of ferromagnesian minerals and the melt between $\sim 0.23$ (orthopyroxene) and 0.38 (amphibole; Sisson and Grove 1993). Measured ratios of 1 imply that post-entrapment modification has caused selective $\mathrm{Fe}-\mathrm{Mg}$ exchange in the mineral and/or melt inclusion.

A systematic study of the behavior of $\mathrm{Mg}$ and $\mathrm{Fe}$ in olivine and its melt inclusions by Danyushevsky et al. (2002a) has shown that post entrapment diffusive reequilibration of olivine crystallized from the melt onto inclusion walls results in an increase in the $\mathrm{Mg} / \mathrm{Fe}$ ratio in the inclusion after homogenization. A similar process to that suggested by Danyushevsky et al. (2002b) for olivine is likely to have affected the Fe and $\mathrm{Mg}$ content of melt inclusions and mafic minerals in our samples, partly explaining the similar $\mathrm{Mg \#}$ in melt inclusions and the host mineral.

In addition to this process, we suggest that mafic minerals exchange $\mathrm{Fe}$ and $\mathrm{Mg}$ with the surrounding melt after the inclusion had solidified. This resulted in a further decrease in the $\mathrm{Mg} \#$ of the host to values close to those measured in the melt inclusions. This also requires that exchange between the mineral and the melt sur-
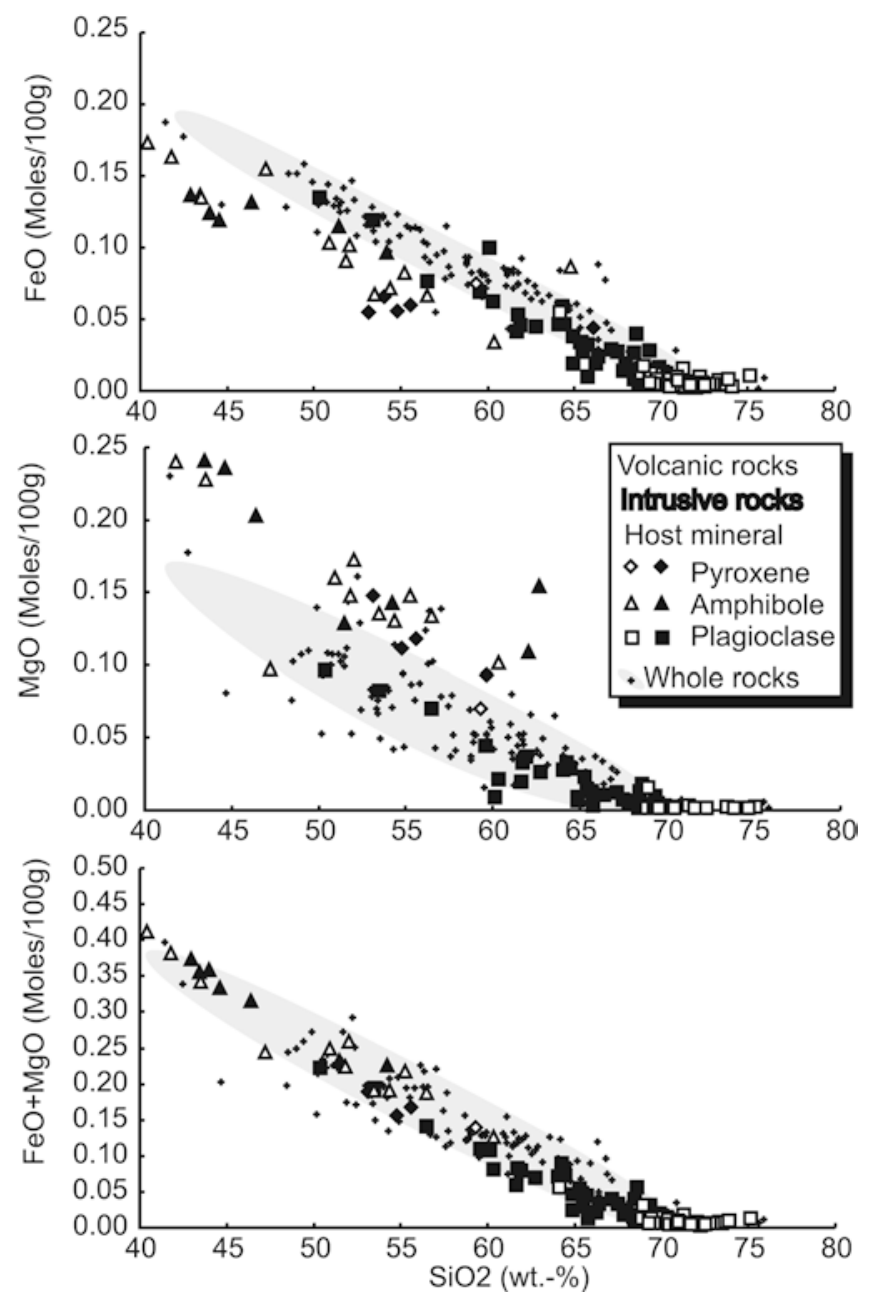

Fig. 6 Molar concentrations of $\mathrm{Fe}, \mathrm{Mg}$ and $\mathrm{Fe}+\mathrm{Mg}$ in melt inclusions and bulk rocks from the Farallón Negro Volcanic Complex. Due to post-entrapment re-equilibration of $\mathrm{Fe}$ and $\mathrm{Mg}$, the concentration of $\mathrm{Fe}$ in melt inclusions trapped in mafic phases is lower, and that of $\mathrm{Mg}$ higher than the corresponding concentrations measured in melt inclusions in plagioclase or in bulk rocks at the same $\mathrm{SiO}_{2}$ content. The sum of $\mathrm{Fe}+\mathrm{Mg}$ in the inclusions, in moles, follows the same tight correlation trend as the bulk rocks, suggesting that a stoichiometric exchange affected $\mathrm{Fe} / \mathrm{Mg}$ ratios only. Shaded areas underline the main bulk rock trends

rounding phenocrysts continued to lower temperatures than the exchange between the mineral and the inclusion melt. The process causing this is unclear, but the concentration of $\mathrm{Fe}$ and $\mathrm{Mg}$ in melt inclusions hosted by mafic phases are cannot be taken as representative of the concentrations in the original melt. Even though the abundance of $\mathrm{Fe}$ and $\mathrm{Mg}$ in melt inclusions from mafic phases appears to be modified, the sum of the molar abundance of these two elements is identical to that measured in plagioclase and in the bulk rocks (Fig. 6). This supports the hypothesis of a stoichiometric FeMg-1 exchange after entrapment of inclusions, rather than an analytical artifact or heterogeneous entrapment.

Besides $\mathrm{Mg}$ and $\mathrm{Fe}$, some other elements also differ significantly in the melt inclusions of the cogenetic pyroxene-plagioclase pair. These are likely to be primary 
differences, in particular for $\mathrm{Cu}$ (see Halter et al. 2004b) and reflect entrapment of the inclusions at slightly different stages in the growth of the plagioclase and the pyroxene.

\section{Sulfide melt inclusions}

\section{Analytical precision}

Earlier tests (e.g., Jackson et al. 1992; Fryer et al. 1995; Longerich et al. 1996; Gunther et al. 1997; Heinrich et al. 2002) have shown that laser-ablation ICPMS is relatively insensitive to matrix effects as long as silicatebased matrices are compared. Sylvester (2001) suggested that accurate quantification of element concentrations in sulfides requires the use of a sulfide as an external standard. The analysis of sulfide melt inclusions in silicate minerals thus poses a potential problem for the quantification of the mixed signal of sulfide melt inclusion + silicate host in variable and initially unknown proportions. We therefore evaluated the applicability of using a silicate glass standard (NIST 610) for calibration of sulfides with the Excimer laser system, by comparing the concentrations of the siderophile elements $\mathrm{Fe}, \mathrm{Ni}$ and $\mathrm{Co}$ and the chalcophile element $\mathrm{Cu}$ to those obtained by EMP on the same synthetic sulfide grains of pyrrhotite, chalcopyrite and millerite (Table 3). Within an uncertainty of one standard deviation, both LA-ICPMS and EMP yield the same results (Fig. 7). The large variation in the $\mathrm{Fe}$ and Co content of one millerite is due to a coupled substitution with $\mathrm{Ni}$.

Controlled ablation of some silicate host minerals (notably quartz) requires a high energy density on the ablation spot, whereas sulfides require lower energy for ablation. Sulfide ablation behavior may be different at high energy densities and therefore, we tested the dependence of sulfide LA-ICPMS analysis upon the laser output energy and ablation spot size. Tests (Fig. 8) demonstrate that these two parameters exert little influence on the results shown in Fig. 7.

Our analytical comparison between the electron microprobe and LA-ICPMS (Fig. 7) shows that for these elements, the calibration of sulfide analyses by external calibration on silicate glass standards is accurate for the beam-homogenized 193-nm laser system employed here-despite the strongly contrasting matrices between standard and sample. This is even true for variable beam energies and differing pit sizes as shown in Fig. 8, as required for the controlled ablation of melt inclusions in any host silicate mineral. These results demonstrate that ratios between siderophile $(\mathrm{Fe}, \mathrm{Co})$ and chalcophile $(\mathrm{Cu}, \mathrm{Ni})$ elements in sulfides can be accurately quantified by the use of silicate glass standards on our instrumental setup. We are therefore confident that the calibration of sulfide melt inclusions hosted by silicate minerals is also accurate for $\mathrm{Au}$ when using a silicate glass as an external standard (Halter et al. 2002a).

\section{Representative sampling}

Petrographic observations on polished surfaces show that sulfide melt inclusions are composed of several sulfide minerals, presumably formed by exsolution and crystallization upon cooling. This observation is confirmed by the signal in Fig. 3, which shows a heterogeneous distribution of $\mathrm{Cu}$ and $\mathrm{Au}$ relative to $\mathrm{Fe}$ within the inclusion. Thus, for a representative analysis of the melt, it is essential that entire inclusions are ablated, whereas spot analysis at the sample surface would not yield true melt compositions.

Figure 3 shows that in heterogeneous inclusions the signal from $\mathrm{Cu}$ and $\mathrm{Au}$ may be a short fraction of the total signal length. This limits the number of determinations for which these two elements (and $\mathrm{Au}$ in particular) generate a signal significantly above the background. This uncertainty in the sampling increases the uncertainty on the element ratios obtained by signal integration, and may be significant for short signals with less than approximately 10 determinations (Pettke et al. 2000). As in other inclusion analyses, the variability of the result in a population of cogenetic inclusions is the best measure of true analytical uncertainty.

\section{Conclusions}

Laser-ablation ICP-MS is a powerful tool for efficient and systematic analysis of major to trace elements in melt inclusions, because it allows complete integration of bulk melt compositions and, thus, the analysis of crystallized inclusions in any phenocryst phase without prior homogenization. Quantification of inclusion compositions is done through the use of an internal standard, which corrects for the crystallization of host mineral onto inclusion walls upon cooling. This is an alternative to thermal homogenization and has the advantage that independent checks on the reconstituted melt composition can be made (e.g., use of various internal standards, use of melt inclusion populations). Heterogeneous entrapment and selective post-entrapment modifications (e.g., through loss of volatiles or alteration) can be identified through the analysis of several inclusions from a single assemblage (Roedder 1984).

The effect of post-entrapment re-equilibration of the $\mathrm{Fe}$ and $\mathrm{Mg}$ content of mafic host minerals has become apparent from analysis of co-existing host minerals and their melt inclusions. It affects $\mathrm{Fe} / \mathrm{Mg}$ ratios, but not their sum, in the inclusion and is not an artifact of the analytical technique; re-melting of a modified host would likewise not yield the $\mathrm{Fe} / \mathrm{Mg}$ ratio in the original melt. Such a modification can potentially affect all elements that easily exchange through substitutions in the crystal lattice. Only $\mathrm{Fe}$ and $\mathrm{Mg}$ appear to be significantly affected by this process in our sample suite, and both elements were, therefore, not used in the geological interpretation of the data (Halter et al. 2004b). 


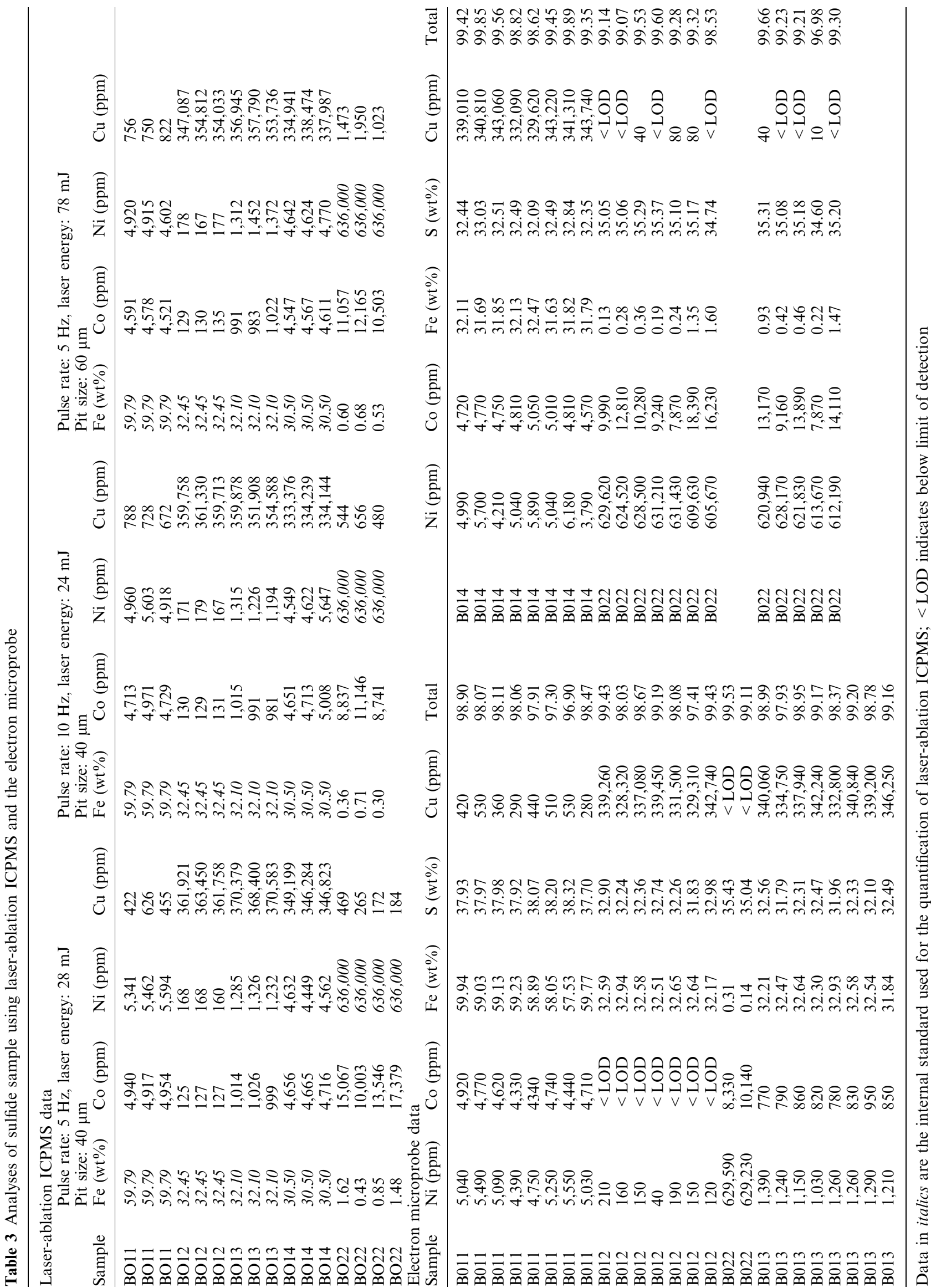




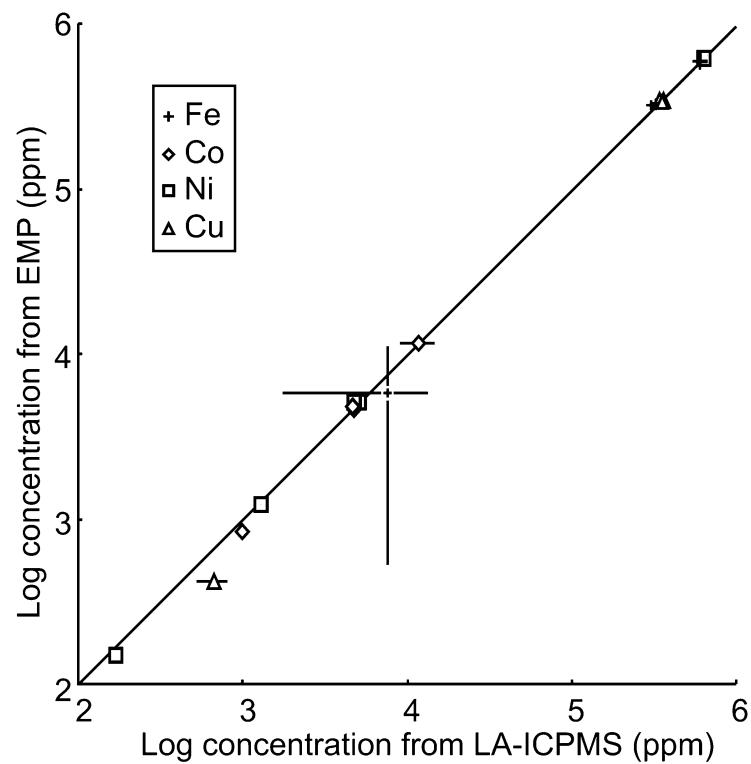

Fig. 7 Comparison of average concentrations of $\mathrm{Fe}, \mathrm{Cu}, \mathrm{Ni}$ and $\mathrm{Co}$ in sulfides obtained with the electron microprobe (five analyses per symbol) and with LA-ICPMS (nine analyses per symbol) calibrated with the glass standard NIST 610. Correspondence of the LAICPMS data with the EMP data demonstrate that the element ratios measured by homogenized Excimer laser ablation are independent of the matrix within a typical sampling precision of a few wt $\%$ RSD

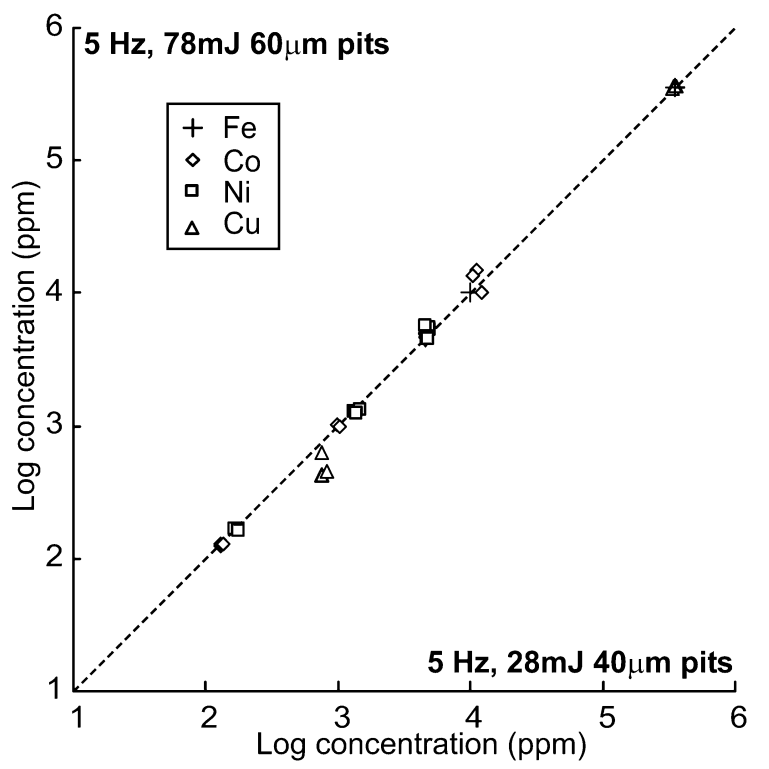

Fig. 8 Comparison between element concentrations in sulfide standards using different pit sizes and laser output energies. The close agreement in the calculated element concentrations demonstrates that the measured ratios between $\mathrm{Fe}, \mathrm{Cu}, \mathrm{Ni}$ and $\mathrm{Co}$ are insensitive to the laser beam energy used for the ablation

Results from melt inclusions trapped simultaneously in different host minerals demonstrate that the mathematical de-convolution of the mixed mineral + melt signal is valid and not influenced by the composition of the host. Moreover, they show that melt inclusions reliably represent samples of the melt from which minerals grew. In particular, the effect of a boundary layer around the growing crystal appears to be negligible for inclusions greater than about $10 \mu \mathrm{m}$ in diameter. Thus, carefully selected melt inclusion assemblages represent true samples of the melt from which the crystal grew, and their composition can be used to reliably derive quantitative information on processes controlling the evolution of magmatic systems.

Acknowledgments The authors would like to thank Minera Alumbrera Ltd. and MIM Exploration for their logistic support during the fieldwork required by this study. Many thanks also go to Tim Grove for extensive discussions of the data and his insight into magmatic systems. We would also like to acknowledge the constructive reviews by Eric Christiansen, Katherine Kelly and Charles Mandeville.

\section{References}

Alard O, Griffin WL, Lorand JP, Jackson SE, O'Reilly SY (2000) Non-chondritic distribution of the highly siderophile elements in mantle sulphides. Nature 407:891-894

Anderson AT, Brown GG (1993) $\mathrm{CO}_{2}$ contents and formation pressures of some Kilauean melt inclusions. Am Miner 78:794 803

Campos E, Touret JLR, Nikogosian I, Delgado J (2002) Overheated, $\mathrm{Cu}$-bearing magmas in the Zaldivar porphyry-Cu deposit, Northern Chile. Geodynamic consequences. Tectonophysics 345:229-251

Danyushevsky LV, McNeill AW, Sobolev AV (2002a) Experimental and petrological studies of melt inclusions in phenocrysts from mantle-derived magmas: an overview of techniques, advantages and complications. Chem Geol 183:5-24

Danyushevsky LV, Sokolov S, Falloon TJ (2002b) Melt inclusions in olivine phenocrysts: using diffusive re- equilibration to determine the cooling history of a crystal, with implications for the origin of olivine-phyric volcanic rocks. J Petrol 43:1651-1671

Dietrich A, Lehmann B, Wallianos A (2000) Bulk rock and melt inclusion geochemistry of Bolivian tin porphyry systems. Econ Geol Bull Soc Econ Geol 95:313-326

Fryer BJ, Jackson SE, Longerich HP (1995) Design, operation and role of the laser-ablation microprobe coupled with an inductively-coupled plasma-mass-spectrometer (Lam-Icp-Ms) in the earth-sciences. Can Mineral 33:303-312

Gaetani GA, Watson EB (2000) Open system behavior of olivinehosted melt inclusions. Earth Planet Sci Lett 183:27-41

Gunther D, Frischknecht R, Heinrich CA, Kahlert HJ (1997) Capabilities of an Argon Fluoride $193 \mathrm{~nm}$ excimer laser for laser ablation inductively coupled plasma mass spectrometry microanalysis of geological materials. J Anal At Spectrom 12:939-944

Halter WE, Pettke T, Heinrich CA (2002a) The origin of $\mathrm{Cu} / \mathrm{Au}$ ratios in porphyry-type ore deposits. Science 296:1844-1846

Halter WE, Pettke T, Heinrich CA, Rothen-Rutishauser B (2002b) Major to trace element analysis of melt inclusions by laserablation ICP-MS: methods of quantification. Chem Geol 183:63-86

Halter WE, Bain N, Becker K, Heinrich CA, Landtwing M, VonQuadt A, Bissig T, Clark AH, Sasso AM, Tosdal RM (2004a) From andesitic volcanism to the formation of a porphyry- $\mathrm{Cu}-\mathrm{Au}$ mineralizing magma chamber: The Farallón Negro Volcanic Complex, northwestern Argentina. J Volcanol Geotherm Res (in press)

Halter WE, Heinrich CA, Pettke T (2004b) Laser-ablation ICP-MS analysis of melt inclusions in an andesitic complex II: Magmas genesis and implications for ore-formation. Contrib Mineral Petrol (in press) 
Hauri E, Wang JH, Dixon JE, King PL, Mandeville C, Newman S (2002) SIMS analysis of volatiles in silicate glasses 1. Calibration, matrix effects and comparisons with FTIR. Chem Geol 183:99-114

Heinrich CA, Pettke T, Halter WE, Aigner M, Audétat A, Günther D, Hattendorf B, Bleiner D, Guillong M, Horn I (2002) Quantitative multi-element analysis of minerals, fluid and melt inclusions by Laser-Ablation Inductively-Coupled-Plasma Mass-Spectrometry. Geochim Cosmochim Acta (in press)

Jackson SE, Longerich HP, Dunning GR, Fryer BJ (1992) The application of laser-ablation microprobe-inductively coupled plasma-mass-spectrometry (LAM-ICP-MS) to in situ traceelement determinations in minerals. Can Mineral 30:1049-1064

Kamenetsky V, Clocchiatti R (1996) Primitive magmatism of Mt Etna: Insights from mineralogy and melt inclusions. Earth Planet Sci Lett 142:553-572

Kamenetsky VS, Eggins SM, Crawford AJ, Green DH, Gasparon M, Falloon TJ (1998) Calcic melt inclusions in primitive olivine at 43 degrees N MAR: evidence for melt-rock reaction/melting involving clinopyroxene-rich lithologies during MORB generation. Earth Planet Sci Lett 160:115-132

Larocque ACL, Stimac JA, Keith JD, Huminicki MAE (2000) Evidence for open-system behavior in immiscible Fe-S-O liquids in silicate magmas: Implications for contributions of metals and sulfur to ore-forming fluids. Can Mineral 38:1233-1249

Llambías EJ (1970) Geologia de los Yacimientos Mineros Agua de Dionisio, Prov. de Catamarca, Rep. Argentina. Revista de la Asociacion Argentina de Mineralogia Petrologia y Sedimentologia 1:2-32

Longerich HP, Gunther D, Jackson SE (1996) Elemental fractionation in laser ablation inductively coupled plasma mass spectrometry. Fresenius J Anal Chem 355:538-542

Lowenstern JB (1994) Dissolved volatile concentrations in an oreforming magma. Geology 22:893-896

Metrich N, Clocchiatti R, Mosbah M, Chaussidon M (1993) The 1989-1990 activity of Etna magma mingling and ascent of $\mathrm{H}_{2} \mathrm{O}$ Cl-S-rich basaltic magma-evidence from melt inclusions. J Volcanol Geotherm Res 59:131-144

Pettke T, Heinrich CA, Ciocan AC, Gunther D (2000) Quadrupole mass spectrometry and optical emission spectroscopy: detection capabilities and representative sampling of short transient signals from laser-ablation. J Anal At Spectrom 15:1149-1155

Pettke T, Webster JD, Halter WE, Heinrich CA, Aigner-Torres M, De Vivo B (2002) Advantages and limitations of quantifying melt inclusion chemistry by LA-ICPMS, EMP and SIMS Geochim Cosmochim Acta 66:A596-A596

Roedder E (1984) Fluid inclusions. Rev Miner, 12. Mineral Soc Am Wash, $644 \mathrm{pp}$

Sisson TW, Grove TL (1993) Experimental investigations of the role of $\mathrm{H}_{2} \mathrm{O}$ in calc-alkaline differentiation and subduction zone magmatism. Contrib Mineral Petrol 113:143-166

Sobolev AV (1996) Melt inclusions in minerals as a source of principle petrological information. Petrology 4:209-220

Sobolev AV, Chaussidon M (1996) $\mathrm{H}_{2} \mathrm{O}$ concentrations in primary melts from supra-subduction zones and mid-ocean ridges: Implications for $\mathrm{H}_{2} \mathrm{O}$ storage and recycling in the mantle. Earth Planet Sci Lett 137:45-55

Sobolev AV, Dmitriev LV, Barsukov VL, Nevsorov VN, Slutsky AB (1980) The formation conditions of the high magnesium olivines from the monomineralic fraction of Luna 24 regolith. In: PR Criswell, Merrill RB (eds) Igneous processes and remote sensing: Proceedings of the Lunar and Planetary Science Conference, 11. (vol) 1, Pergamon, New York, pp 105-116

Sobolev AV, Shimizu N (1993) Ultra-depleted primary melt included in an olivine from the Mid-Atlantic Ridge. Nature 363:151-154

Sylvester P (2001) A practical guide to platinum-group element analysis of sulphides by laser-ablation ICPMS. In: Sylvester P (ed) Laser-ablation in the earth sciences: principles and application. Mineral Assoc Can 29:203-213

Taylor RP, Jackson SE, Longerich HP, Webster JD (1997) In situ trace-element analysis of individual silicate melt inclusions by laser ablation microprobe inductively coupled plasma-mass spectrometry (LAM-ICP-MS). Geochim Cosmochim Acta 61:2559-2567

Thomas JB, Bodnar RJ, Shimizu N, Chesner C (2002) What boundary layer? Evidence from melt inclusions in plagioclase, quartz, allanite and zircon from the Toba Tuffs, Sumatra, Indonesia. In: Kontak DJ, Anderson AJ (eds), Eighth Biennial Pan-American Conference on Research on Fluid Inclusions, Halifax, Nova Scotia, pp 103-104

Wallace PJ, Anderson AT, Davis AM (1995) Quantification of preeruptive exsolved gas contents in silicic magmas. Nature 377:612-616

Webster JD, Kinzler RJ, Mathez EA (1999) Chloride and water solubility in basalt and andesite melts and implications for magmatic degassing. Geochim Cosmochim Acta 63:729738 